BISMA

(Bisnis dan Manajemen)
Volume 13, Issue 2, April 2021, 108-120

ISSN 2549-7790 (Online)

ISSN 1979-7192 (Print)

DOI: 10.26740/bisma.v13n2.p108-120

https://journal.unesa.ac.id/index.php/bisma/index

\title{
Improving MSMEs performance through entrepreneurial marketing, entrepreneurial networking, and product innovation
}

\author{
Eva Mufidah ${ }^{1 *}$, Anis Eliyana \\ ${ }^{1,2}$ Universitas Airlangga, Indonesia \\ ${ }^{1}$ Universitas Merdeka Pasuruan, Indonesia
}

\begin{abstract}
This study aims to determine how MSMEs can improve their performance through entrepreneurial marketing, entrepreneurial networking, and product innovation. The research design uses purposive sampling method with a total sample of 135 MSMEs. The data analysis uses multiple linear regression through SPSS to determine whether the three variables affect MSMEs performance. This study explains that the variables entrepreneurial marketing and entrepreneurial networking encourage MSMEs performance improvement. Nevertheless, product innovation does not affect MSMEs performance. This result provides contribution to MSMEs, consumers, and the government about the strategy to improve MSMEs' product innovation.
\end{abstract}

Keywords: entrepreneurial marketing; entrepreneurial networking; MSMEs; performance; product innovation.

Received: June 6, 2020; Accepted: August 18, 2020; Published: April 27, 2021

*Corresponding author

Email: eva.mufidah-2019@feb.unair.ac.id

To cite this document:

Mufidah, E. \& Eliyana, A. (2021). Improving MSMEs performance through entrepreneurial marketing, entrepreneurial networking, and product innovation. BISMA (Bisnis dan Manajemen), 13(April), 108-120. https://doi.org/10.26740/bisma.v13n2.108-120.

\section{INTRODUCTION}

Economic growth in Indonesia is one of the essential factors in improving the welfare of the community, especially those in lower middle class. The performance of MSMEs depends on how effectively MSMEs allocate scarce resources from limited working capital and efficient labor to achieve the MSME strategy (Cao \& Zhang, 2011; Teirilinck \& Spithoven, 2013). MSMEs growth in the Pasuruan city has unique trend since it encouraged by the young entrepreneurs (Kabupaten Pasuruan, 2019). This is because of their awareness to innovate the results that can support the economy both for small families and society in general (Scuotto et al., 2017). 
Mufidah, E. \& Eliyana, A.

Improving MSMEs performance through entrepreneurial marketing, entrepreneurial networking, and product innovation

Entrepreneurship as the process of producing new works using enthusiasm, energy and time, and capital spent accompanied by risk and uncertainties. The result will be rewarded when the business is successful. According to Syapsan (2019), entrepreneurial orientation affects marketing performance through marketing capabilities and competitive strategies.

Research from several experts stated that there is a significant influence of entrepreneurial networking on performance (Moghli \& Al Muala, 2012; Li et al., 2015; Asad et al., 2016). Meanwhile, Wahyuningsih (2017) also stated that the marketing performance of MSMEs is influenced by entrepreneurial networking. Septiani et al. (2013) explained that entrepreneurial marketing positively influences small industries' competitiveness. Moreover, marketing performance measures the effectiveness of a marketing strategy to achieve company goals.

In 2018, there are more than one thousand MSMEs with various sectors in Pasuruan city (Kabupaten Pasuruan, 2019). These MSMEs are required to have expertise in good entrepreneurial networking, entrepreneurial marketing, and must innovate on the products. According to Arfanly et al. (2017), entrepreneur must have good strategic skills for existing businesses with entrepreneurial marketing. According to Hurley \& Hult (2012), the existence of rapid and varied technological changes will show that there has been product innovation that can create a competitive advantage. Rapid technological advances and high levels of competition require every effort to make a product innovation continuously. This study aims to determine how MSMEs can improve their performance through entrepreneurial marketing, entrepreneurial networking, and product innovation.

\section{Performance}

Hacioglua et al. (2012) classified performance into two groups internal performance (financial) and external performance (marketing). Becherer et al. (2012) explained work performance correlates with the organization strategic objectives, customer satisfaction, and contribution to the economy. The company performance is a multidimensional construct. In this case, company performance consists of financial performance, business performance, and organizational performance.

Septiani et al. (2013) mentioned performance is the level of implementation of tasks that can be achieved by someone using existing capabilities and boundaries set to achieve organizational goals. According to Wahyuningsih (2017), company performance indicator comprises: sales growth, customer growth, profit growth, and working capital growth.

\section{Entrepreneurial Marketing}

The importance of entrepreneurship and innovation for marketing to success in entrepreneurial activities, the combination of this two fields is needed for success in entrepreneurship (Sadiku-Dushi et al., 2019). In entrepreneurial marketing, all organizational function should open communication to customers and build customer relationships characterized by innovation, risk-taking, and proactiveness (Kraus et al., 2011). Sidharta \& Sidh (2013) explained the relationship of entrepreneurial opportunity and intention on company performance. This shows that people will not start entrepreneurship before they have the intention and realise the opportunity. 
According to Hatta \& Hariyani (2015), entrepreneurial marketing is a proactive attitude by taking advantage of opportunities to acquire and retain customers through an innovative approach to taking risks, creating value, and optimize resources. In contrast to the Miles et al. (2014) study, entrepreneurial marketing as a theory that focuses on how individuals and management accept risk innovatively and proactively. Entrepreneurial marketing is more focused on creating market needs rather than meeting market needs. At the strategic level, entrepreneurial marketing practices a bottom-up approach that identifies market opportunities. Then, testing it through a trial and error process starts serving customer needs and extending it by making direct contact to obtain information according to customer needs (Miles et al.,2014).

There are four indicators of entrepreneurial marketing: (1) the concept of marketing companies that focus on the orientation of innovation and the existence of ideas as a tool to meet market needs; (2) marketing strategy that implements the bottom-up process following client demand; (3) marketing method to make an active approach or contact directly with customers; and (4) market intelligence that use an informal approach such as personal observation (Stokes \& Wilson, 2010). Therefore, this study hypothesize:

H1: Entrepreneurial marketing is significantly influence MSMEs performance.

\section{Entrepreneurial Networking}

According to Covin et al. (2012), entrepreneurial networking explains that social networks can influence entrepreneurial activities and decisions. There were few research about the impact of business networks on entrepreneur performance, so this research focuses on developing marketing networks and business networks by small entrepreneurs. Alvarez (2012) explained that most entrepreneurs do not have sufficient business skills, which results in entrepreneurs tending to seek help related to the functional aspects of their business and some technical aspects which they consider to be still lacking.

There are some of new entrepreneur challenges such as a lack of information because they have not yet entered the formal network system. Their existence outside the formal system makes them isolated from the latest ideas and trends, which are detrimental to their position in the market (Usai et al., 2018). Other things that can also harm entrepreneurs are information lacking about regulators, suppliers, customers, and sources of funds and growth opportunities that cannot be accessed if they do not join formal business networks (Tabares et al., 2021). Formal business networks are networks facilitated by a collection of users, universities, and government agents. This network routinely has access to training and workshop funds for business development (Usai et al., 2018).

Networking is activity-oriented in building and managing personal relationships with specific individuals in their environment (Tipu \& Arain, 2011). Raija (2011) explained that the more networks that contain experts from connected partners, the more information channels offered and the entrepreneurial team will absorb information better. There are three aspects of network and networking: (1) social, communication, business, and morals as determinants; (2) formal or informal, voluntary-compulsory, directly, and indirect networks; and (3) objectives of the business (Premaratne, 2002). Hence, this study hypothesize:

$\mathrm{H} 2$ : Entrepreneurial networking is significantly influence MSMEs performance. 
Mufidah, E. \& Eliyana, A.

Improving MSMEs performance through entrepreneurial marketing, entrepreneurial networking, and product

Product Innovation

innovation

Competitive advantage is the primary key to survive in the globalization era. According to Hurley \& Hult (2012), product innovation impacts rapid technological changes, and high product variations will determine competitive advantage. Product innovations produced by MSMEs are expected to improve products' competitiveness at the local, national, and international levels.

Innovation is an idea, practice, or object that is considered new by another individual or user unit (Hills \& Hultman, 2011). Innovation as a psychological and socio-cultural phenomenon, both aspects can be the key to the success or failure of an organization (Daghfous et al., 2015). According to Scarbrough et al., (2015), innovation is a complex process involving various organizations' social groups. Meanwhile, Mehran \& Zeinab (2018) explained innovation means that a firm is actively looking for new opportunities rather than simply use the existing strenghts and likely to surpass customer expectations. Therefore, this study hypothesize:

H3: Product innovation is significantly influence MSMEs performance.

\section{METHODS}

This study examines MSMEs in Pasuruan city. In 2019, the MSMEs in this city about 900. According to Arikunto (2016), if the population is less than 100, all should be taken as sample. If the population is large, then sample can be taken $10-15 \%$ of the population. In this study, samples were $15 \%$ of the total population. Hence, the sample used was 135 MSMEs. The sampling method using a purposive sampling method with $>5$ years company age as the requirement of sample selection.

This study was collected data through questionnaire. Before conducting research, researchers also conduct preliminary research to test the reliability and validity of the questionnaire with 38 respondents as samples. Furthermore, to answer the hypothetical questions raised by the researchers, this study uses multiple linear regression analysis.

\section{RESULT AND DISCUSSION Preliminary Study}

Researchers conducted a preliminary study by completing an instrument test on 38 respondents to test the validity and reliability. Validity testing uses pearson correlation coefficient, which is declared valid if it has a significance value smaller than the 5\% significance level. Reliability testing, using the cronbach alpha value if a construct or variable is declared reliable at the cronbach alpha value greater than 0.6 (Arikunto, 2016). The following results of the validity testing are presented in Appendix 1, Appendix 2, and Appendix 3.

Appendix 1 explains whether the questionnaire is valid or not by a significant value that greater than the level 5\%. From the results, the entrepreneurial marketing variable obtained a correlation coefficient of greater than $5 \%$, so that the results of testing of entrepreneurial marketing are declared valid. Appendix 2 presents the validity test of the entrepreneurial networking variable by using the Pearson correlation coefficient, which states that the variable is valid if the significance value is greater than the real level of $5 \%$. The results show the variable entrepreneurial networking obtained a significance value greater than the real level of $5 \%$, so that the variable was entrepreneurial networking declared valid. Appendix 3 presents 
the validity test of the product innovation variable by using the Pearson correlation coefficient where the variable is declared valid if a significant value is greater than $5 \%$ level. The product innovation variable results obtained a significant value above the real level of $5 \%$, so that the product innovation variable is declared valid. From the Appendix 4 result, the validity test of performance variable was conducted by Pearson correlation coefficient where the performance variable is declared valid if the significance value obtained is greater than the real level of $5 \%$. The performance variable obtained a significance if above $5 \%$, so that the performance variable is declared valid.

After the preliminary study, each variable namely entrepreneurial marketing, entrepreneurial networking, product innovation, and MSMEs performance are valid. This is based on a significant value above the real level of 5\%. In Appendix 5, it is also known that the variables in this study are said to be reliable. cronbach alpha value indicates this for the variables entrepreneurial marketing, entrepreneurial networking, product innovation, and performance getting values greater than 0.6.

After testing the validity and reliability to determine whether the variables in this study are valid and reliable, then the next hypothesis is tested. In multiple linear regression, analysis assumptions are tested first. One of them is the assumption of multicollinearity.

Multicollinearity testing aims to test whether the regression model found a correlation between independent variables. The three independent variables were analyzed by their collinearity using two criteria: VIF and tolerance value. A variable is free of multicollinearity if the VIF value is less than ten and the value tolerance is greater than 0.10 (Appendix 6). The test results stated that there was no collinearity between the independent variables involved in the study. This is evidenced by the VIF value and value tolerance of each independent variable smaller than ten and greater than 0.10. The test results are presented in Appendix 6.

\section{Descriptive Analysis}

Entrepreneurial marketing variable was measured by indicators: concepts, strategies, methods, and intelligence. Meanwhile, entrepreneurial networking measured by three indicators: determinants, links, and objectives. Based on Appendix 9, the mean and median values of three indicators implies most MSMEs entrepreneur in Pasuruan city agreed that business network influence MSMEs performance. Moreover, product innovation is measured by three aspects, namely X3.1, X3.2, and X3.3. The result shows product innovation and sales techniques influence MSMEs performance.

MSMEs performance is measured from four indicators: sales growth; customer growth, profit growth, and working capital growth. Based on Appendix 8, most MSMEs entrepreneur agreed to support the implementation of a good MSMEs performance to improve the MSMEs sustainability.

\section{The Goodness of the Regression Model}

Appendix 7 shows coefficient determination about 78,7\%. This means that entrepreneurial marketing, entrepreneurial networking, and product innovation to MSMEs performance in Pasuruan city was 78.7\%. In comparison, the remaining $21.3 \%$ was explained by other variables not included in this study. The simultaneous regression model in Appendix 8 shows that a formed regression model of entrepreneurial marketing, entrepreneurial 
Mufidah, E. \& Eliyana, A.

Improving MSMEs performance through entrepreneurial marketing, entrepreneurial networking, and product innovation networking, and product innovation influence the MSMEs performance in Pasuruan city. This is evident from each model's significance value with a smaller significance level of $5 \%$.

Based on Table 1, entrepreneurial marketing has a significant value on the MSMEs performance with a regression coefficient of 0.629 and a significant value of 0.000 . Entrepreneurial marketing has a positive influence on the performance of MSMEs. Meanwhile, the entrepreneurial networking variable has a significant influence on MSMEs performance with a regression coefficient of 0.285 and a significant value of 0.000 . Entrepreneurial networking has a positive influence on the performance of MSMEs. For product innovation, there is no significant effect on the performance of MSMEs in Pasuruan city. This is evidenced by the significance value of 0.885 that greater than the $5 \%$ real level.

Table 1. Partial Test of T Test Regression

\begin{tabular}{|c|c|c|c|c|c|c|}
\hline \multirow{2}{*}{ Variable } & \multicolumn{2}{|c|}{$\begin{array}{l}\text { Unstandardized } \\
\text { Coefficients }\end{array}$} & \multirow{2}{*}{$\begin{array}{c}\text { Standardized } \\
\text { Coefficients } \\
\text { Beta }\end{array}$} & \multirow{2}{*}{$\mathbf{t}$} & \multirow{2}{*}{ Sig. } & \multirow{2}{*}{ Result } \\
\hline & B & $\begin{array}{c}\text { Std } \\
\text { Error }\end{array}$ & & & & \\
\hline Constant & 1.435 & 1.005 & & & & \\
\hline Ent. Marketing & 0.614 & 0.078 & 0.629 & 7.902 & 0.000 & Significant \\
\hline $\begin{array}{l}\text { Ent. Networking } \\
\text { Product Innovation }\end{array}$ & $\begin{array}{l}0.387 \\
0.016\end{array}$ & $\begin{array}{l}0.106 \\
0.109\end{array}$ & $\begin{array}{l}0.285 \\
0.008\end{array}$ & $\begin{array}{l}3.640 \\
0.145\end{array}$ & $\begin{array}{l}0.000 \\
0.885\end{array}$ & $\begin{array}{c}\text { Significant } \\
\text { No significant }\end{array}$ \\
\hline
\end{tabular}

\section{Discussion}

Entrepreneurial marketing provides a positive and significant impact on MSMEs performance in Pasuruan city. This results support Arfanly et al. (2017) research that entrepreneurial marketing is more focused on creating market needs than following consumers' needs. Entrepreneurial marketing needs a strategy to identify market opportunities to get market share under MSMEs' expectations. Besides, MSMEs must also be proactive in identifying and exploiting various business opportunities to retain customers. This research confirms Hamamali (2013) that entrepreneurial marketing affects innovation, marketing performance, and financial performance.

The MSMEs must know the indicators of entrepreneurial marketing according to Stokes \& Wilson (2010), which is expected to provide great opportunities for the development of MSMEs businesses in the city of Pasuruan. Some indicators that can increase market share for businesses include: (1) product marketing that focuses on the orientation of innovation and ideas as a tool to meet market needs; (2) the marketing of products that practice the bottom-up process under client demand; (3) the marketing products mix by taking an active approach or direct contact with customers; and (4) market intelligence is corporate marketing using informal information such as personal observation.

This study confirms Oktarina et al. (2020) research that stated about the innovation role to improve performance, especially in marketing aspect. The four indicators above can be used determine the MSMEs strategy to increase market share and business opportunities in Pasuruan City. This study also supports Becherer et al. (2012) that entrepreneurial marketing affects financial performance and customer growth and success and emphasize Morrish et al. (2010) study that entrepreneurial marketing is an integrative conceptualisation that reflects the marketing dimension's perspective based on resource excellence. 
The variable entrepreneurial networking also gives a positive and significant influence on the performance of MSMEs in Pasuruan city. The current MSMEs must realize that the formal network system is very important for their businesses' survival. Therefore, the MSMEs must connect to the formal network system that can connect with various interested parties, including suppliers, regulators, customers, sources of funds, and the government. This result supports Abbas et al. (2019) research that entrepreneurial networking focuses on the maturity of MSMEs in building a relationship system and developing fot working together to achieve firm business objectives.

The role of entrepreneurial networking is essential in the sustainability of MSMEs businesses in Pasuruan city. By applying the three indicators of MSMEs performance indicator by Premaratne (2002) as a measurement of strategy effectiveness in business development, MSMEs may increase market opportunities and economic growth of Pasuruan city.

The product innovation does not have a significant effect on MSMEs performance in Pasuruan city. The MSMEs have financial limitations that cause them to be less able to create new models on the products produced. Besides, limited innovative ideas of entrepreneur can affect the performance of MSMEs in Pasuruan city. Product innovation is one of competitive advantage element to remain survive in the globalization era. According to Hurley \& Hult (2012), product innovation impacts rapid technological changes, and high product variations will determine the competitive advantage. A product innovation produced by MSMEs is expected to improve product competitiveness at the local, national, and international levels.

It is expected that product innovation can be a strategy for MSMEs entrepreneurs to improve their business development. Nevertheless, product innovation at the MSMEs in Pasuruan city does not have a significant influence. This is because of MSMEs have the limited funds, lack of innovation (new products) to attract buyers and did not get any local government training. Therefore, the local government and stakeholders should support the MSMEs entrepreneurs to create product innovation for business sustainability.

In line with the opinion of Gatignon \& Xuereb (1997), product innovation in MSMEs consists of three critical things: product excellence, product uniqueness, and production costs. Product innovation can fail due to errors in implementing strategies, including product design that is not innovative, incorrect estimating competition issues, and high production costs. Innovation is a process of change in organization and is the key to win customer and market (Kanagal, 2015).

Then, there will be more product innovations and product choices that will be marketed to consumers with the options and advantages of each with the product's distinctiveness. Furthermore, MSMEs businesses can continue to developing their product that become a signature of Pasuruan city.

\section{CONCLUSION}

Based on the analysis results, several conclusions can be drawn as follows: (1) entrepreneurial marketing has a significant and positive influence and improves MSMEs performance in Pasuruan city; (2) entrepreneurial networking has a significant and positive impact and improves MSMEs performance in Pasuruan city; and (3) product innovation does not have a significant influence toward MSMEs performance in Pasuruan city. 
Mufidah, E. \& Eliyana, A.

Improving MSMEs performance through entrepreneurial marketing, entrepreneurial networking, and product innovation

The limitation of this study is the scope of research which only examines MSMEs performance in Pasuruan city so that the research results cannot generalize to the same phenomenon in Indonesia. Furthermore, this study does not categorize MSMEs based on the type of company (manufacturing or trading) and or based on B2B or B2C business model which can explain in detail which aspects of the product are innovatively developed. Therefore, in the future, MSMEs in Pasuruan are expected to create product innovations that can continue to advance and maintain the MSMEs industries' survival. This study suggests the further research to explore other variables that can support progress for the growth of MSMEs in Pasuruan city and maintain the sustainability of the MSMEs industry, such as marketing innovation.

\section{REFERENCES}

Abbas, J., Raza, S., Nurunnabi, M., Minai, M. S., \& Bano, S. (2019) The Impact of Entrepreneurial Business Networks on Firms Performance Through a Mediating Role of Dynamic Capabilities. Suistainability, 11(11). https://doi.org/10.3390/su11113006.

Alvarez, S. A., Barney, J. B., \& Anderson, P. (2012). Forming and Exploiting Opportunities: The Implications of Discovery and Creation Process for Entrepreneurial and Organizational Research. Organizational Science, 24(1). 301-317. https://doi.org/10.1287/orsc.1110.0727.

Arfanly, B. E., Sarma, M., \& Syamsun, M. (2017). Peran Entrepreneurial Marketing dalam Meningkatkan Kinerja Pemasaran pada industri Rumahan Kabupaten Kendal Jawa Tengah. Manajemen IKM, 11(2), 141-150. https://doi.org/10.29244/mikm.11.2.141150.

Arikunto, S. (2016). Prosedur Penelitian Suatu Pendekatan Praktik. Jakarta: Rineka Cipta.

Asad, M., Sharif, M. N. M., \& Alekam, J. M. E. (2016). Moderating Effect of Entrepreneurial Networking on the Relationship between Access to Finance and Performance of Micro and Small Enterprises. Sci.Int. (Lahore), 28(2), 1551-1556. http://www.sciint.com/pdf/636327862716332643.-PAID.pdf.

Becherer, R. C., Helms, M. M., \& McDonald, J. P. (2012). The Effect of Entrepreneurial Marketing on Outcome Goals in SMEs. New England Journal, 15(1), 7-18. https://doi.org/10.1108/NEJE-15-01-2012-B001.

Cao, M. \& Zhang, Q (2011). Supply Chain Collaboration: Impact on Collaborative Advantage and Firm Performance. Journal of Operation Management, 29(3), 163-180. https://doi.org/10.1016/j.jom.2010.12.008.

Covin. J. G. \& Wales. W. J. (2012). The Measurement of Entrepreneurial Orientation. Entrepreneurship Theory and Practice, 36(4), 677-702. https://doi.org/10.1111/j.15406520.2010.00432.x.

Daghfous N., Petrof, J. V., \& Pons F. (2015) The Influence of Values on New Product Adoption: A Cross-Cultural Study. In: Chebat JC., Oumlil A. (eds) Proceedings of the 1998 Multicultural Marketing Conference. Developments in Marketing Science: Proceedings of the Academy of Marketing Science. Springer, Cham. https://doi.org/10.1007/978-3-319-17383-2_17. 
Gatignon, H. \& Xuereb, J-M. (1997). Strategic Orientation of the Firm and New Product Performance. Journal of Marketing Research, 34(1), 77-79. https://doi.org/10.1177/002224379703400107.

Hacioglua, G., Eren S. S., Eren, M. S., \& Celikkan, H. (2012). The Effect of Entrepreneurial Marketing on Firms Inovative Performance in Turkish SMEs. Turkish: Procedia-Social and Behavioral Sciences, 58, 871-878. https://doi.org/10.1016/j.sbspro.2012.09.1065.

Hatta \& Haryani, I. (2015). Orientasi Pasar, Orientasi Kewirausahaan, Kapabilitas Pemasaran, dan Kinerja Pemasaran. Jurnal Aplikasi Manajemen. 13(4). https://jurnaljam.ub.ac.id/index.php/jam/article/view/815/764.

Hamamali, S. (2013). Increasing Innovation Through Entrepreneurial Marketing and The Impact on Marketing Performance on Garment SMEs in West Java. West Java: Proceeding- National Conference Suistainable Competitive Advantages.

Hills, G. E. \& Hultman, C. (2011). Research in Marketing and Entrepreneurship: a Retrospective Viewpoint. Journal of Research in Marketing and Entrepreneurship, 13(1), 8-17. https://doi.org/10.1108/14715201111147914.

Hurley, R. F. \& Hult, G. T. M. (2012). Innovation, Market Orientation, and Organizational Learning: An Integration and Empirical Examination. Journal of Marketing, 62(3), 4254. https://doi.org/10.2307/1251742.

Kabupaten Pasuruan. (2019). Jumlah Usaha Mikro di Kabupaten Pasuruan Semakin Berkembang Pesat. Retrieved December 30, 2020 from https://www.pasuruankab.go.id/berita-4143-jumlah-usaha-mikro-di-kabupatenpasuruan-semakin-berkembang-pesat-.html.

Kanagal, N. B. (2015) Innovation and Product Innovation in Marketing Strategy. Journal of Management and Marketing Research, 18(Februari), 1-25. https://www.aabri.com/manuscripts/152209.pdf.

Kraus. S., Harms. R., \& Fink. M. (2011). Moving Beyond Marketing in The New Ventures. International Journal of Entrepreneurship and Innovation Management, 11(1), 19-34. https://doi.org/10.1504/IJEIM.2010.029766.

Li, H., Zubielqui, G., \& O'Connor, A. (2015). Entrepreneurial Networking Capacity of Cluster Firms: A Social Network Perspective on How Shared Resources Enhance Firm Performance. Small Business Economics, 45(3), 523-541. https://doi.org/10.1007/s11187-015-9659-8.

Mehran. R. \& Zeinab. (2018). The Impact of Entrepreneurial Marketing on Innovative Marketing Performance in Small and Medium Sized Companies. Journal of Strategic Marketing, 28(2), 136-148. https://doi.org/10.1080/0965254X.2018.1488762.

Miles, M., Gilmore, A., Harrigan, P., Lewis, G., \& Sethna, Z. (2014). Exploring Entrepreneurial Marketing. Journal of Strategic Marketing, 23(2), 94-111. https://doi.org/10.1080/0965254X.2014.914069. 
Mufidah, E. \& Eliyana, A.

Improving MSMEs performance through entrepreneurial marketing, entrepreneurial networking, and product innovation

Moghli, A. A. \& Al Muala, A. (2012). Impact of Entrepreneurship Network in the Success of Business on going Stage in Jordanian manufacturing Companies. American Academic \& Scholary Research Journal 4(2), 31-40. https://www.semanticscholar.org/paper/IMPACT-OF-ENTREPRENEURIAL-

NETWORKS-IN-THE-SUCCESS-Abou-MoghliMuala/673bdfd42ad028405830a1c7623f12ebe28a0120.

Morrish. S. C., Miles. M. P., \& Deacon. J. H. (2010) Entrepreneurial Marketing: Acknowledging the Entrepreneur and Customer-Centric Interrelationship. Journal of Strategic Marketing, 18(4), 303-316. https://doi.org/10.1080/09652541003768087.

Oktarina, N. \& Murwatiningsih. (2020). Creating Innovation Based on Superior Business Capabilities and Entrepreneurial Network to Enhance Marketing Performance. KnE Social Sciences, 4(6), 613-626. https://doi.org/10.18502/kss.v4i6.6631.

Premaratne, S. (2002). Network, Resources, and Small Business Growth: The Experience in Srilanka, Journal of Small Business Management, 39(4), 363-371. https://doi.org/10.1111/0447-2778.00033.

Raija Leskinen. (2011). Success in the Female Entrepreneurial Networking Process. Annals of Innovation \& Entrepreneurship. 2(1). 6002. https://doi.org/10.3402/aie.v2i1.6000.

Sadiku-Dushi, N., Dana, L. P., \& Ramadani, V. (2019). Entrepreneurial marketing dimensions and SMEs performance. Journal of Business Research, 100(C), 86-99. https://doi.org/10.1016/j.jbusres.2019.03.025.

Scarbrough, H., D. Andreta, D., Evans, S., Marabelli, M., Newel, S., Powell, J., \& Swan, J. (2015). Network innovation in The Health Sector: Comparative Qualitative Study of the Role of Collaborations for Leadership in Applied Health Research and Care in Translating research Into Practice. Health Services and Delivery Research, 2(13). 1-128. https://doi.org/10.3310/hsdr2130.

Scuotto, V., Del Giudice, M., Bresciani, S., \& Meissner, D. (2017). Knowledge-Driven Preferences in Informal Inbound Open Innovation Modes. An Explorative View on Small to Medium Enterprises. Journal of Knowledge Management, 21(3). https://doi.org/10.1108/JKM-10-2016-0465.

Septiani, S., Sarma, M., \& Limbong, W. H. (2016). Pengaruh Entrepreneurial Marketing dan Kebijakan Pemerintah terhadap Daya Saing Industri Alas Kaki di Bogor. Jurnal Manajemen dan Organisasi, 4(2). https://doi.org/10.29244/jmo.v4i2.12617.

Sidharta, I. \& Sidh, R. (2013). Analisis Faktor-Faktor Sikap yang Membentuk Niat Mahasiswa menjadi Teknopreneur. Jurnal Computech \& Bisnis, 7(2), 117-128. Retrieved May 10 2020 from https://mpra.ub.uni-muenchen.de/77076/.

Stokes. D. \& Wilson, N. (2010) Small Business Management and Entrepreneurship (6th ed) Andover: Cengage Learning. https://doi.org/10.1108/14715200080001536.

Syapsan, S. (2019). The effect of Service Quality, Innovation Towards Competitive Advantages and Suistanable Economic Growth Marketing Mix Strategi as mediating 
variable. Benchmarking: An International Journal, 26(4), 1336-1356. https://doi.org/10.1108/BIJ-10-2017-0280.

Tabares, A., Chandra, Y., Alvarez, C., \& Escobar-Sierra, M. (2021). Opportunity-related behaviors in international entrepreneurship research: a multilevel analysis of antecedents, processes, and outcomes. International Entrepreneurship and Management Journal, 17(1), 321-368. https://doi.org/10.1007/s11365-020-00636-3.

Teirilinck. P. \& Spithoven. A. (2012). Formal R\&D Management and Strategic Decision Making in Small Firms in Knowledge-Intensive Business Services. R\&D Management. 43(1). 37-51. https://doi.org/10.1111/j.1467-9310.2012.00701.x.

Tipu, S. A. A. \& Arain, F. M. (2011). Managing Success Factors in Entrepreneurial Ventures: A Behavioral Approach. International Journal of Entrepreneurial Behaviour \& Research, 17(5), 534-560. https://doi.org/10.1108/13552551111158844.

Usai, A., Scuotto, V., Murray, A., Fiano, F., \& Dezi, L. (2018). Do Entrepreneurial Knowledge and Innovative Attitude Overcome "Imperfections" in the Innovation Process? Insights from SMEs in the UK and Italy. Journal of Knowledge Management, 22(8), 1637-1654. https://doi.org/10,1108/JKM-01-2018-0035.

Wahyuningsih, S. E. (2017). Membangun Jejaring Kewirausahaan melalui Keunggulan Usaha Konveksi untuk Meningkatkan Kinerja Pemasaran. Teknobunga, 4(1), 76-94. https://doi.org/10.15294/teknobuga.v4i1.13853.

Appendix 1. Results of Validity Testing Entrepreneurial Marketing

\begin{tabular}{lccl}
\hline \multicolumn{1}{c}{ Indicator } & $\begin{array}{c}\text { Correlation } \\
\text { Coefficient }(\mathbf{r})\end{array}$ & Sig. Value & Result \\
\hline X1.1 Concept & & & \\
X1.1.1 & 0.625 & 0.000 & Valid \\
X1.1.2 & 0.650 & 0.000 & Valid \\
X1.1.3 & 0.846 & 0.000 & Valid \\
X1.2 Strategy & & & \\
X1.2.1 & 0.709 & 0.000 & Valid \\
X1.2.2 & 0.624 & 0.000 & Valid \\
X1.3 Method & & & \\
X1.3.1 & 0.626 & 0.000 & Valid \\
X1.3.2 & 0.692 & 0.000 & Valid \\
X1.4 Market & & & \\
Intelligence & & & Valid \\
X1.4.1 & 0.743 & 0.000 & Valid \\
X1.4.2 & 0.792 & 0.000 & Valid \\
X1.4.3 & 0.570 & 0.000 & Valid \\
X1.4.4 & 0.636 & 0.000 & \\
\hline
\end{tabular}


Mufidah, E. \& Eliyana, A. Improving MSMEs performance through entrepreneurial marketing, entrepreneurial networking, and product innovation

Appendix 2. Results of Validity Testing Entrepreneurial Networking

\begin{tabular}{lccc}
\hline \multicolumn{1}{c}{ Indicator } & $\begin{array}{c}\text { Correlation } \\
\text { Coefficient (r) }\end{array}$ & Sig. Value & Result \\
\hline X2.1 Determinant & & & \\
X2.1.1 & 0.723 & 0.000 & Valid \\
X2.1.2 & 0.741 & 0.000 & Valid \\
X2.1.3 & 0.821 & 0.000 & Valid \\
X2.2 Link & 0.746 & 0.000 & Valid \\
X2.3 Objective & & & \\
X2.3.1 & 0.711 & 0.000 & Valid \\
X2.3.2 & 0.700 & 0.000 & Valid \\
\hline
\end{tabular}

Appendix 3. Results of Validity Testing Product Innovation

\begin{tabular}{lccc}
\hline Indicator & $\begin{array}{c}\text { Correlation } \\
\text { Coefficient }(\mathbf{r})\end{array}$ & Sig. Value & Result \\
\hline X3.1 & 0.619 & 0.000 & Valid \\
X3.2 & 0.678 & 0.000 & Valid \\
X3.3 & 0.755 & 0.000 & Valid \\
\hline
\end{tabular}

Appendix 4. Results of Validity Testing Performance

\begin{tabular}{cccc}
\hline Indicator & $\begin{array}{c}\text { Correlation } \\
\text { Coefficient }(\mathbf{r})\end{array}$ & Sig. Value & Result \\
\hline Y1.1 & 0.690 & 0.000 & Valid \\
Y1.2 & 0.788 & 0.000 & Valid \\
Y1.3 & 0.791 & 0.000 & Valid \\
Y1.4 & 0.783 & 0.000 & Valid \\
\hline
\end{tabular}

Appendix 5. Reliability Test Results

\begin{tabular}{lcc}
\hline \multicolumn{1}{c}{ Variable } & Alpha Cronbach's Value & Result \\
\hline Entrepreneurial Marketing & 0.887 & Reliable \\
Entrepreneurial Networking & 0.835 & Reliable \\
Product Innovation & 0.735 & Reliable \\
Performance & 0.762 & Reliable \\
\hline
\end{tabular}

Appendix 6. Multicolllinearity Testing Results

\begin{tabular}{lccc}
\hline \multicolumn{1}{c}{ Independent Variable } & VIF & Tolerance Value & Result \\
\hline Entrepreneurial Marketing & 3.980 & 0.251 & There is no \\
Entrepreneurial Networking & 3.848 & 0.260 & multicollinearity \\
Product Innovation & 1.919 & 0.521 & \\
\hline
\end{tabular}

Appendix 7. Determination Coefficient of Regression

\begin{tabular}{cccc}
\hline Model & $\mathbf{R}$ & $\begin{array}{c}\text { Adj } \mathbf{R} \\
\text { Square }\end{array}$ & Independent Variable \\
\hline 1 & 0.890 & 0.787 & $\mathrm{X} 1, \mathrm{X} 2, \mathrm{Z}$ \\
\hline
\end{tabular}

Appendix 8. Simultaneous Testing with F Test of Regression Model

\begin{tabular}{clcccccc}
\hline \multirow{2}{*}{ Model } & & $\begin{array}{c}\text { Sum of } \\
\text { Square }\end{array}$ & df & $\begin{array}{c}\text { Mean } \\
\text { Square }\end{array}$ & F & Sig. & Result \\
\hline \multirow{2}{*}{1} & Regression & 1148.53 & 3 & 382.85 & 165.89 & 0.000 & Significant \\
& Residual & 302.33 & 131 & 2.31 & & & \\
& Total & 1450.86 & 134 & & & & \\
\hline
\end{tabular}


BISMA (Bisnis dan Manajemen) Volume 13 Issue 2, April 2021 Page 108-120

E-ISSN 2549-7790, P-ISSN 1979-7192

Appendix 9. Descriptive Analysis Variables

\begin{tabular}{lccc}
\hline \multicolumn{1}{c}{ Indicator } & Mean & Median & $\begin{array}{c}\text { Standard } \\
\text { Deviation }\end{array}$ \\
\hline X1 Ent Marketing & & & \\
X1.1 Concept & 4.02 & 4.00 & 0.926 \\
X1.2 Strategy & 4.00 & 4.00 & 0.946 \\
$\quad$ X1.3 Method & 3.99 & 4.00 & 1.007 \\
$\quad$ X1.4 Market Intelligence & 4.00 & 4.00 & 1.058 \\
X2 Ent Networking & & & \\
$\quad$ X2.1 Determinant & 4.04 & 4.00 & 0.937 \\
$\quad$ X2.2 Link & 4.02 & 4.00 & 0.910 \\
$\quad$ X2.3 Objective & 3.96 & 4.00 & 0.976 \\
X3 Product Innovation & & & \\
$\quad$ X3.1 Design Product & 4.16 & 4.00 & 0.812 \\
$\quad$ X3.2 Technological Changes & 4.20 & 4.00 & 0.721 \\
$\quad$ X3.3 Product variations & 4.29 & 4.00 & 0.679 \\
Y Performance & & & \\
$\quad$ Y1.1 Sales Growth & 4.00 & 4.00 & 0.962 \\
$\quad$ Y1.2 Customer Growth & 4.07 & 4.00 & 0.986 \\
$\quad$ Y1.3 Profit Growth & 4.04 & 4.00 & 0.984 \\
Y1.4 Working Capital & 4.01 & 4.00 & 0.938 \\
\hline
\end{tabular}

